\title{
A microstructure comparison of Iron borides formed on AISI 1040 and D2 steels
}

\author{
J. L. Bernal-Ponce ${ }^{1}$, A. Irvin-Martínez ${ }^{1}$, E. Vera-Cárdenas ${ }^{1}$, A. García-Barrientos ${ }^{2}$, A. Medina-Flores ${ }^{3}$, \\ L. Béjar-Gómez ${ }^{3}$, A. Juanico ${ }^{4}, \mathrm{~S}$. Borjas-García ${ }^{5}$, \\ 1. Automotive Mechanics Department, Universidad Politécnica de Pachuca, Hidalgo, México. \\ 2. Electronics Department, Universidad Autónoma del Estado de Hidalgo, Hidalgo, México. \\ 3. Metallurgical Research Institute, UMSNH, Michoacán, México. \\ 4. Industrial and Materials Department, Universidad Politécnica del Valle de México, Tultitlán, México. \\ ${ }^{5 .}$ Institute of Mathematical and Physical, UMSNH, Michoacán, México.
}

Due to its special properties, boron compounds are developed by numerous ways, .i.e. boronizing gas, molten salt boronizing, with and without electrolysis and pack boronizing. Pack boronizing have attracted increasing interest from the technological and scientific point of view, further it has the advantage of simplicity and cost-effectiveness with other boronizing techniques [1]. Wearing resistance, toughness and corrosion, oxidation resistance, and hardness are some of the properties that are significantly enhanced by this thermochemical diffusion process [2-4]. These interesting properties are related with the microstructure that make these coatings excellent candidates to use in applications involving sliding contact and abrasion wear situations [5]. The phase formed in the substrate, its thickness and morphology have interest for study because they are related to their properties. In the present study, the microstructural characterization of iron borides developed at different temperatures by pack-boronizing has been carried out in a AISI 1040 carbon steel and a AISI D2 alloy steel.

The AISI 1040 and AISI D2 were borided. The samples had a disc shape with a diameter of $18 \mathrm{~mm}$ and a thickness of $3 \mathrm{~mm}$. Prior to the boriding process; the samples were polished, ultrasonically cleaned in an alcohol solution and deionized water for 15 minutes at room temperature, and dried and stored under clean-room conditions. Then the samples were embedded in a closed cylindrical case, containing a fresh Durborid powder mixture. The active boron is then supplied by the powder quantity placed over and around the material surface. The powder-pack boriding process was performed in a conventional furnace under a pure argon atmosphere. The boriding process was carried out at two different temperatures $1220 \mathrm{~K}$ and $1320 \mathrm{~K}$ for a time of $8 \mathrm{~h}$. The boriding temperatures were selected according to the position of the solidus line in the Fe-B phase diagram. Once the treatment was completed, the container was removed from the furnace and slowly cooled to room temperature. Finally, the presence of borides formed on the surface of AISI 1040 and AISI D2 steels were confirmed by Scanning Electron Microscopy (SEM), Energy Dispersive Spectroscopy (EDS) and X-Ray Diffraction (XRD) techniques. Figure 1 shows (SEM) images of boron deposited on the surface of AISI D2 and AISI 1040 steels, the XRD scans (Figure 2) of the borided samples confirmed the presence of a single FeB phase formed in the D2 steel at $1220 \mathrm{~K}$ (Fig. 2a) and $1320 \mathrm{~K}$ (Fig. 2c). A double phase borided layer $\mathrm{FeB}+\mathrm{Fe}{ }_{2} \mathrm{~B}$ was confirmed by XRD in the AISI 1040 samples treated at $1220 \mathrm{~K}$ (Fig. 2b) and $1320 \mathrm{~K}$ (Fig. 2d). $\mathrm{Fe}_{2} \mathrm{~B}$ layers has a columnar morphology and dense structure. The depth of borides formed on AISI D2 is lower than that of AISI 1040 as expected. The chemical composition of borided samples are given in Table 1 showing that all samples contain deposited boron on its surface. These results demonstrate that the process of boron powder-pack applied to AISI 1040 and AISI D2 steels formed superficial layer FeB or $\mathrm{Fe}+\mathrm{Fe}_{2} \mathrm{~B}$ depending on the heat treatment and the chemical composition. 
[1] Keddam, Chentouf SM. A diffusion model for describing the bilayer growth $\left(\mathrm{FeB} / \mathrm{Fe}_{2} \mathrm{~B}\right)$ during the iron powder-pack boriding. Appl Surf Sci. 252 (2005), p. 393

[2] Bektes M, Uzun O, Akturk A, Ekinci AE, Ucar N. Vickers microhardness studies of Fe-Mn binary alloys. Chin J Phys 42 (2004), p. 733.

[3] Xu CH, Xi JK, Gao W. Improving the mechanical properties of boronized layers by superplastic boronizing. J Mater Process Technol 65 (1997), p. 94

[4] Ucisik AH, Zeytin S, Bindal C. Boride coating on iron based alloys. J Aust Ceram Soc 37(1) (2001), p. 83.

[5] M.A. Béjar, E. Moreno. Abrasive wear resistance of boronized carbon and low alloy steels. Journal of Materials Processing Technology 173 (2006), p. 352

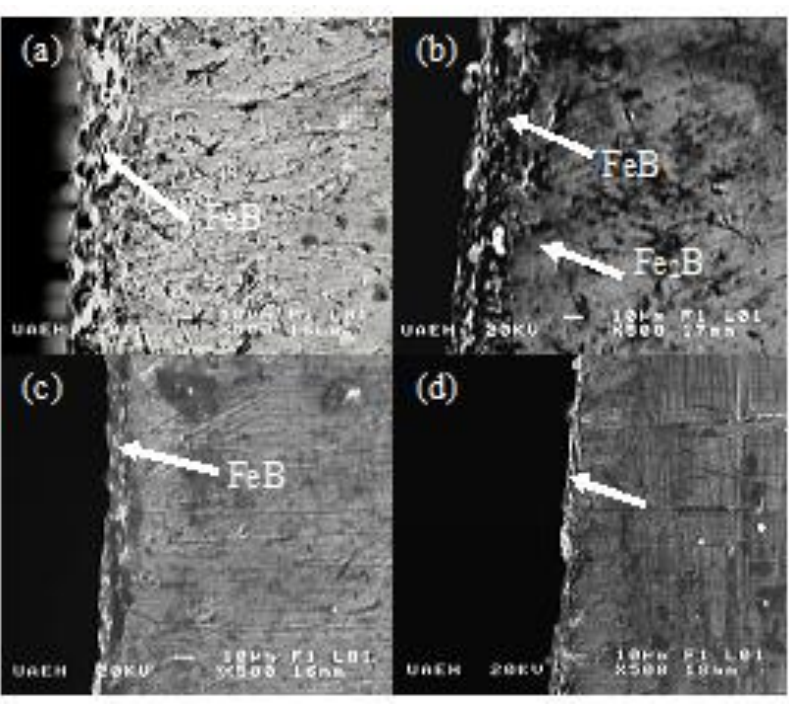

Fig. 1

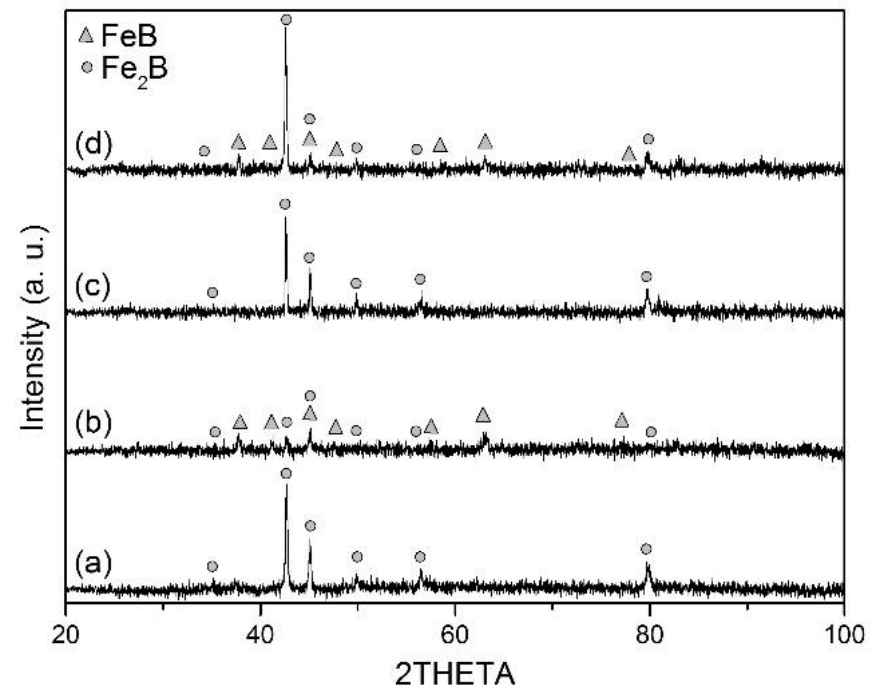

Fig. 2

Figure 1. SEM cross-sectional micrograph, and XRD (Fig. 2) diffraction patterns of borided samples: (a) AISI D2 at $1220 \mathrm{~K}$, (b) AISI 1040 at $1220 \mathrm{~K}$, (c) AISI D2 at $1320 \mathrm{~K}$, (d) AISI 1040 at $1320 \mathrm{~K}$.

\begin{tabular}{|c|c|c|c|c|c|c|c|c|c|c|c|}
\hline $\begin{array}{l}\text { Borided } \\
\text { sample }\end{array}$ & C & $\mathrm{Cr}$ & Mo & $\mathrm{V}$ & $\mathrm{Si}$ & $\mathrm{Ni}$ & $\mathrm{Mn}$ & $S$ & $\mathrm{P}$ & B & $\mathrm{Fe}$ \\
\hline $\begin{array}{l}\text { AISI D2 } \\
1220^{\circ} \mathrm{K}\end{array}$ & 10.25 & 4.73 & 0 & 1.17 & 0.68 & 0 & 0 & 0 & 0 & 11.34 & 71.82 \\
\hline $\begin{array}{c}\text { AISI } 1040 \\
1220^{\circ} \mathrm{K}\end{array}$ & 19.63 & 0 & 0 & 0 & 0 & 0 & 0.31 & 0.01 & 0.02 & 10.32 & 69.71 \\
\hline $\begin{array}{l}\text { AISI D2 } \\
1320^{\circ} \mathrm{K}\end{array}$ & 7.81 & 4.22 & 0 & 1.04 & 0.13 & 0 & 0.20 & 0 & 0.03 & 15.76 & 70.81 \\
\hline $\begin{array}{c}\text { AISI } 1040 \\
1320^{\circ} \mathrm{K}\end{array}$ & 19.07 & 0 & 0 & 0 & 0 & 0 & 1.06 & 0.02 & 0 & 17.15 & 62.70 \\
\hline
\end{tabular}

Table 1. The chemical composition of borided samples [wt. \%] 